\title{
Scurvy in a man with schizophrenia
}

\section{Mark Dubé MD}

See related practice article by Smith and colleagues at www.cmaj.ca/lookup/doi/10.1503/cmaj.091938.

Competing interests: None declared.

This article has been peer reviewed.

\section{Affiliation: From the}

Clinical Sciences Division, Northern Ontario School of Medicine, Sudbury, Ont.

\section{Correspondence to:}

Dr. Mark Dubé, markdubemd@gmail.com

CMAJ 2011. DOI:10.1503 /cmaj.080505

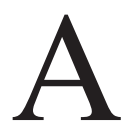
56-year-old man with a history of paranoid schizophrenia presented to the emergency department with a threeweek history of a worsening rash on his lower limbs (Figure 1; Appendix 1, available at www .cmaj.ca/lookup/suppl/doi:10.1503/cmaj.080505 /-/DC1) and oral bleeding thought to be coming from his gums. His diet was poor, with minimal intake of fruits and vegetables. His complete blood count showed normocytic-normochromic anemia, with a hemoglobin level of 102 (normal 140-170) $\mathrm{g} / \mathrm{L}$ and a normal platelet count. The international normalized ratio, liver enzyme, electrolyte and creatinine levels were all within their reference ranges. The serum ascorbic acid concentration was undetectable at less than 10 (normal $>25$ ) $\mu \mathrm{mol} / \mathrm{L}$. The more sensitive buffy coat test for leukocyte ascorbic acid levels was not performed. Radiography was not performed. The patient was diagnosed with scurvy and was given vitamin C, $500 \mathrm{mg}$ orally twice daily. His rash resolved completely within two weeks. He declined follow-up blood tests.

Scurvy is the syndrome of vitamin C deficiency. It can manifest as subcutaneous and other hemorrhages, muscle weakness and corkscrew hair. Soft gums can result in loose teeth. Other clinical findings may include fatigue, keratitis, psychosis and pericardial effusion. ${ }^{1}$ The differential diagnosis includes vasculitides, such as Wegener granulomatosis, ChurgStrauss syndrome and microscopic polyangiitis. The characteristic finding of corkscrew hair may be mistaken for Menkes syndrome. ${ }^{2}$

Vitamin C (L-ascorbate) is a simple 6-carbon sugar that is absorbed in the proximal ileum. ${ }^{3}$ It enhances the absorption of dietary iron and plays a key role in the development and stability of collagen. ${ }^{1}$ Hence, vitamin $\mathrm{C}$ deficiency results in fragility in collagen structures, such as blood vessel walls.

The recommended daily allowances for vitamin $C$ in Canada are $90 \mathrm{mg} / \mathrm{d}$ for men and $75 \mathrm{mg} / \mathrm{d}$ for women, with an additional $45 \mathrm{mg} / \mathrm{d}$

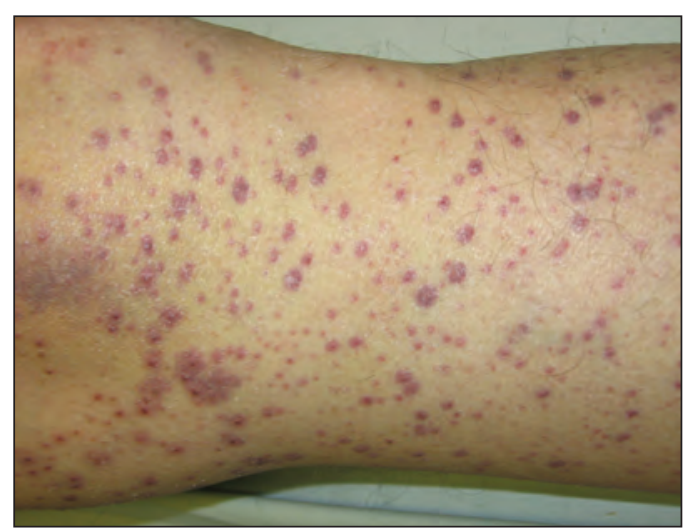

Figure 1: Rash on the leg of a 56-year-old man showing the classic perifollicular hyperkeratotic papules with hemorrhagic haloes. Corkscrew hairs are not evident, because they break easily.

for women who are breastfeeding. ${ }^{4}$ Food sources high in vitamin $\mathrm{C}$ include citrus fruit and juice, sweet peppers, cantaloupe, kiwi, mangos and papayas. Contrary to popular belief, boiling does not destroy the vitamin $\mathrm{C}$ in food. Given the increased availability of fresh fruits and vegetables in developed countries, most reported instances are found in marginalized populations, including people with substance abuse, cognitive impairment or mental illness. ${ }^{1}$ Those with reduced dietary intake or malabsorption syndromes from surgery or disease may also be affected. It is important to note that children of parents who follow restrictive dietary fads may be at increased risk. $^{5}$

\section{References}

1. Hirschmann JV, Raugi GJ. Adult scurvy. J Am Acad Dermatol 1999;41:895-906.

2. Swartz EN. A child with kinky hair. CMAJ 2002;166:1442-3.

3. Bluck LJ, Jones KS, Coward WA, et al. The "anomalous" absorption of labeled and unlabeled vitamin C in man. Br J Nutr 2005;98:627-32.

4. Vitamin C. Ottawa (ON): Health Canada; 2007. Available: www.hc-sc.gc.ca/dhp-mps/alt_formats/hpfb-dgpsa/pdf/prodnatur /mono_vitamin_c-eng.pdf (accessed 2009 Nov. 20).

5. Ratanachu-Ek S, Sukswai P, Jeerathanyasakun Y, et al. Scurvy in pediatric patients: a review of 28 cases. J Med Assoc Thai 2003;86(Suppl 3):S734-40. 